\title{
Board composition and firms' profitability: Empirical evidence from pharmaceutical industry in India
}

\author{
Najib H. S. Farhan \\ College of Business Administration, \\ Arab Open University, \\ KSA \\ najib720000@gmail.com
}

\author{
Mosab I. Tabash \\ College of Business, \\ Al Ain University, \\ $U A E$ \\ mosab.tabash@aam.ac.ae
}

\section{Faozi A. Almaqtari}

Department of Accounting,

Hodeidah University, Hodeidah,

Yemen

Fouzigazim@yahoo.com

\author{
Ali T. Yahya \\ Department of Management, University of Science and Technology \\ Hodeidah, Yemen \\ ali.ust77@gmail.com
}

Abstract. The current study aims to assess the effect of board of directors' composition on the profitability of Indian pharmaceutical companies. The analysis is based on 82 companies, analyzed over ten years, from 2008 to 2017. The least squares regression model is used for analysing the data. One accountingbased measure (return on assets, ROA) and one marketing-based measure (Tobin Q) are used as proxies for firms' profitability. Leverage, firms' size and age are used as control variables. The findings reveal that board of directors' composition as measured by the percentage of independent board members negatively and significantly affects firm's profitability measured by ROA. On the other hand, board of directors' composition positively and significantly affects profitability measured by Tobin Q. Furthermore, firms' size and age positively and significantly impact profitability. This topic is largely neglected by researchers of Indian origin at home and abroad. The present study provides an insight for

Received: September, 2019

1st Revision:

March, 2020

Accepted:

July, 2020

DOI:

$10.14254 / 2071$ 8330.2020/13-3/12 
pharmaceutical companies to consider a high level of professionalism of their board members. Greater board independence could bring more expertise, improving profitability. Accordingly, the current research has implications for board members of pharmaceutical companies, especially government-owned ones.

Keywords: board composition, return on assets, Tobin Q, pharmaceutical firms, India.

JEL Classification: L22, L26

\section{INTRODUCTION}

Corporate governance practices are best defined as mechanisms and processes for managing and monitoring business units' affairs, thus enhancing transparency and accountability (Zabri, Ahmad, \& Wah, 2016). These practices are considered as a matter of concern for many Asian countries, especially after the Asian financial crisis of 1997 (Zabri et al., 2016). In developing countries, corporate governance has been gaining more importance as many firms go through substantial transformations due to socio-political change, economic trends towards globalization and various aspects of technological progress.

Corporate governance theory concentrates on the relationships between management and shareholders of a firm. The ownership structure of companies, the subtle and diverse relationships between owners and managers as well as a sophisticated network of stakeholders together influence the behaviour of management (Rabelo \& Vasconcelos, 2002). It is believed that lower cost of capital, greater likelihood of overcoming periods of crisis, better financial opportunities, better liquidity and easier access to international finance are the results of good corporate governance (Nilsson, 2007).

Promoting transparency is the main reason behind corporate governance initiatives to reduce agency costs (Bassen, 2004). To improve corporate governance in the pharmaceutical sector, the government should be able to estimate the efficient capacity of institutional collaboration, coordination and cooperation which can be used as governance practice. This estimation increases the opportunities for improving measurement and analysis, improving information systems and transforming needs into solutions (Fuentes, 2013).

Recently, attention among academics and other researchers has been shifting towards the concepts and techniques of corporate governance and their role in increasing shareholder interest (e.g., Mallin 2001; Mueller, 2006; Burton, 2000). The research questions often concern the overall composition of the board of directors. More specifically, heterogeneous boards are beneficial for Indian companies. Board heterogeneity means variety among directors, where the board includes members of different nationality, ethnic background, age, educational level, gender, and occupational background (Kang, Cheng \& Gray, 2007, p. 195). The existing research on corporate governance and firms' profitability posits that agency problems can be reduced through board of directors. It is well known that shareholders and management have different interests in the organization. Therefore, the board of directors plays a major role in reducing the conflict between management and shareholders and acts as an agent; thus, agency costs are reduced (Mahadeo, Soobaroyen, \& Hanuman, 2012).

Based on agency theory, Fama and Jensen (1983) and also Core, Holthausen, and Larcker (1999) advocated that independent directors act in favor of shareholders as they maintain close supervision over business activities, and usually have less collusion with management. It is well known that independent board members have the reputation of safeguarding shareholders' interests. However, dependent directors 
are more influenced by the CEO, giving them personal benefits, especially those related to their career (Bebchuk \& Fried, 2003; Weisbach, 2007). Nevertheless, independent directors can also negatively impact the internal governance of a firm if they maintain a secret relationship with management. Research also finds that external board directors are less prone to fraud, and agency theory confirms that an external board of directors should effectively monitor both top management and the board itself. Krause et al. (2014) and other researchers agree with this theory as they believe that independent board directors are totally independent from management. Similarly, Gordon (2007) believed that one of the benefits gained from assigning independent directors is that they are not under the influence of management and are totally independent from them. Some scholars, regulators and investors believe that an independent board of directors is an important corporate governance tool to monitor management. However, they cannot prevent corporate scandals from occurring; an example is Enron Company which had 11 independent directors out of 14 members on the board (Bhagat \& Black, 2002). The need to optimize shareholders' wealth requires sound corporate governance mechanisms that focus on enhancing the economic efficiency of a firm. The board, including executive and non-executive directors, monitors management. Usually, investors prefer more independent directors on the board. Agrawal and Knoeber (1996) believed that the board of directors is positively related to firms' profitability. Similarly, board independence has a positive impact on profitability (Jackling \& Johl, 2009). Board composition has a low and positive correlation with profitability (Rhoades, Rechner \& Sundaram, 2017). Johl, Kaur, and Cooper (2015) believe that board independence does not significantly affect performance. Arora (2012) advocated that firms' performance is negatively affected by the board of directors' composition. On the contrary, Alabdullah, Yahya, Nor and Majeed (2016) advocate that firms' profitability is not affected by the number of independent board directors.

The pharmaceutical sector is ranked third in the world in terms of manufacturing volumes and technologies used. It has more than 20,000 registered units. Approximately 250 units are large and organized; they control about $70 \%$ of the market (Geethalakshmi \& Jothi, 2016; Vijayalakshmi \& Srividya, 2015). Of the 250 companies that dominate the $70 \%$ of the market, 141 were listed on the Bombay Stock Exchange (BSE) as of 28/04/2018, and this is the target population of this study. The pharmaceutical market of India is considered as the fastest growing on the globe. The industry has an annual growth of between $8 \%$ and $9 \%$. It produces around $10 \%$ of global needs (Geethalakshmi \& Jothi, 2016). The objective of this study is to make a contribution to the literature by evaluating the effect of board composition on firms' profitability in a specific context, India. The business environment in India is somewhat different from that of other countries. The composition of boards of directors in the pharmaceutical industry is an interesting study, as this industry has been rather neglected in terms of research coverage.

In this paper we attempt to investigate the relationship between the board of directors' composition and the profitability of pharmaceutical companies, using Return On Assets (ROA) and Tobin Q. We cover ten years from 2008 to 2017, and 82 pharmaceutical companies. The remainder of our paper is organized as follows: Section 2 is the literature review; Section 3 illustrates the research design and methods; Section 4 analyses and interprets the results; and Section 5 concludes the study.

\section{LITERATURE REVIEW}

The issue of board of directors' independence occupies an important place in corporate governance developments, given the many corporate scandals which introduced the public to inadequate board supervision, and hence close relationships between executive and management (e.g., Higgs, 2003; Brennan $\&$ McDermott, 2004). Taking the agency theory view, many scholars have focused on the structure, operation and composition of the board of directors and their effect on firms' profitability (e.g., SamraFredericks, 2000; Erhardt, Werbel \& Shrader, 2003; Essayed, 2007). and several have concluded that 
corporate governance has a significant role in the firm's profitability. Talamo (2011) analysed existing corporate governance rules and identified the key determinants of corporate governance mechanisms. Aren, Kayagil and Aydemir (2014) investigated the mechanisms and effects of corporate governance of firms operating in the Istanbul Stock Exchange (ISE). The study sample size comprised 162 ISE listed companies, and it was found that firms' value is the most crucial factor for enhancing the level of corporate governance. It was also revealed that substantial value mediates the association between the ratio of corporate investor and corporate governance levels. On the other hand, growing corporate governance implementation is positively associated with firms' performance.

Mahadeo et al. (2012) evaluated the link between board of directors' composition and firms' profitability. The study sample comprised Canadian companies. Using cross-sectional regression analyses, findings revealed that appropriate team size, team tenure and moderate levels of variation in age and high levels of experience correlate with profitability. Yameen, Farhan and Tabash (2019) examined the impact of board of directors' composition on firms' profitability, focusing on the Indian hotel industry. Panel data analysis of 39 hospitality firms covering the period 2014 to 2016 revealed that the board of directors' composition negatively influences the profitability of Indian hotels.

Mohamed et al. (2016) investigated the impact of corporate governance practices on the profitability of Top 100 Malaysian companies. They used board size and board of directors' independence to explain the practice of corporate governance, return on equity and return on assets to measure profitability. Descriptive, correlation and regression analysis were used to establish and examine research hypotheses, revealing that board of directors' size was significantly and negatively associated with return on assets, but insignificantly correlated with return on equity. Ameer, Ramli and Zakaria (2010) also sought to evaluate the relationship between corporate governance, specifically board composition, and firms' profitability. They used linear regression for analysing a panel data set of 277 Malaysian companies covering five years from 2002 to 2007, and found that a larger proportion of independent members on the board was related to better profitability. Pillai and Al-Malkawi (2017) also found that internal attributes of corporate governance have an impact on the profitability of firms. The study applied panel data analysis to selected firms from the Gulf region and found that government shareholding, corporate social responsibility, board size, audit type and leverage significantly influenced the firms' financial performance in most of the GCC countries. Conyon \& He (2011, 2012) and Byrd and Cooperman (2010) aimed to find the relationship between an external board of directors and executives' compensation. However, some research found a negative correlation between executive composition and the number of external board members. Other studies found no association between external directors and executive composition. Javid and Iqbal (2008) conducted a study in Pakistan and found that independent boards have a positive association with CEOs' pay.

Priego and Merino (2016) aimed to identify ownership and board characteristics and investigate the effect on the likelihood of financial distress in Spain. Spanish listed firms' data from 2007 to 2012 was analysed using a matched-pairs research design. The findings confirmed that the effect of board ownership and board independence on the likelihood of business failure was the same in difficult situations before bankruptcy, as well as in more extreme conditions.

Switzer and Tang (2009) also found a positive relationship between firms' profitability and the proportion of board independence by examining 245 companies from 2000 to 2004. Chatterjee (2011) and Rhoades et al. (2017) also analysed the relationship between firms' performance and board independence, revealing that it was not significant. On the other hand, Agrawal and Knoeber (1996) found a significant correlation between attributes of the board and firms' value, while Jackling and Johl (2009) found that board independence significantly influenced profitability. However, Johl et al. (2015) believed that board independence does not affect firms' profitability. Arora (2012) advocated that composition of the board of directors has a negative effect on firms' profitability. On the other hand, Alabdullah et al. (2016) believed 
that board independence has an insignificant effect on performance. Table 1 summarizes the important studies related to the effect of board of directors' composition on firms' profitability.

To sum up, both empirical evidence and theoretical argument regarding the role of the heterogeneous or homogeneous nature of boards of directors in improving corporate performance remains inconclusive. The published work is largely confined to developed countries such as the UK, USA and Australia. Kang et al. (2007) suggested that similar studies should be undertaken in other counties to compare the results of different regions. Hence, this research investigates the effect of board composition on the profitability of Indian pharmaceutical companies.

Table 1

Summary of some previous research regarding board of directors composition and firms performance

\begin{tabular}{|c|c|c|c|c|c|c|c|}
\hline Author & Aim & $\begin{array}{c}\text { Dependent } \\
\text { Variables }\end{array}$ & $\begin{array}{c}\text { Independent } \\
\text { Variables }\end{array}$ & Methods & Country & $\begin{array}{l}\text { Sample } \\
\text { Size }\end{array}$ & Findings \\
\hline $\begin{array}{l}\text { López-arceiz, } \\
\text { Bellostas- } \\
\text { pérezgrueso, } \\
\text { Marianoand } \\
\text { Rivera-torres } \\
\text { (2017) }\end{array}$ & $\begin{array}{l}\text { "To examine the } \\
\text { impact that CSR } \\
\text { disclosure as a } \\
\text { transparency } \\
\text { mechanism, and good } \\
\text { CG practices on the } \\
\text { financial performance } \\
\text { of socially responsible } \\
\text { firms" }\end{array}$ & $\begin{array}{l}\text { Tobin Q and } \\
\text { ROE }\end{array}$ & $\begin{array}{l}\text { "General } \\
\text { meeting, board } \\
\text { of directors, } \\
\text { support } \\
\text { committees, and } \\
\text { CSR disclosure } \\
\text { accessibility" }\end{array}$ & $\begin{array}{l}\text { Simultaneous } \\
\text { equations }\end{array}$ & Spain & $\begin{array}{c}174 \\
\text { Companies }\end{array}$ & $\begin{array}{l}\text { "Findings suggest that firms } \\
\text { that wish to rise fund from the } \\
\text { financial markets should } \\
\text { develop both: a good CG and } \\
\text { a high level of CSR disclosure, } \\
\text { as part of their CSR strategy". }\end{array}$ \\
\hline Chatterjee(2011) & $\begin{array}{l}\text { "Evaluate the } \\
\text { relationship between } \\
\text { board composition } \\
\text { and performance in } \\
\text { Indian firms" }\end{array}$ & Tobin Q & $\begin{array}{l}\text { "Board size and } \\
\text { board } \\
\text { independence" }\end{array}$ & $\begin{array}{l}\text { Multiple } \\
\text { regression } \\
\text { model }\end{array}$ & India & 420 Firms & $\begin{array}{l}\text { "Board size and board } \\
\text { independence have an } \\
\text { insignificant impact on the } \\
\text { performance of Indian PSUs". }\end{array}$ \\
\hline $\begin{array}{l}\text { Arora and } \\
\text { Sharma(2015) }\end{array}$ & $\begin{array}{l}\text { "To examine the } \\
\text { impact of firms } \\
\text { performance on board } \\
\text { composition" } \\
\end{array}$ & $\begin{array}{l}\text { ROA, ROE, } \\
\text { NPM, Tobin } \\
\text { Q and stock } \\
\text { returns }\end{array}$ & $\begin{array}{l}\text { "Board size, } \\
\text { independence } \\
\text { and annual } \\
\text { meetings" } \\
\end{array}$ & - & - & 1922 Firms & $\begin{array}{l}\text { "larger board, outside } \\
\text { membership and more } \\
\text { meetings are considered as } \\
\text { expensive affairs in the firms" }\end{array}$ \\
\hline $\begin{array}{l}\text { Mahadeo et } \\
\text { al.(2012) }\end{array}$ & $\begin{array}{l}\text { "To examine the key } \\
\text { elements of board } \\
\text { diversity amongst } \\
\text { listed companies and } \\
\text { their influence on the } \\
\text { financial } \\
\text { performance" }\end{array}$ & $\begin{array}{l}\text { Financial } \\
\text { performance }\end{array}$ & Board diversity & $\begin{array}{l}\text { Descriptive, } \\
\text { correlation, } \\
\text { and regression }\end{array}$ & Sri Lanka & $\begin{array}{c}42 \\
\text { Companies }\end{array}$ & $\begin{array}{l}\text { It was found that here is a } \\
\text { satisfactory level of } \\
\text { heterogeneity in the board of } \\
\text { directors in terms of age, } \\
\text { independence and educational } \\
\text { background }\end{array}$ \\
\hline Beasley(2016) & $\begin{array}{l}\text { "To examine whether } \\
\text { more independent } \\
\text { board of directors } \\
\text { significantly reduces } \\
\text { the likelihood of } \\
\text { financial statement } \\
\text { fraud" }\end{array}$ & $\begin{array}{l}\text { Financial } \\
\text { fraud }\end{array}$ & $\begin{array}{l}\text { Board } \\
\text { composition }\end{array}$ & $\begin{array}{l}\text { Descriptive, } \\
\text { correlation and } \\
\text { regression }\end{array}$ & - & $\begin{array}{l}75 \text { no-fraud } \\
\text { firms and } 75 \\
\text { fraud firms }\end{array}$ & $\begin{array}{l}\text { "No-fraud firms have boards } \\
\text { with significantly higher } \\
\text { percentages of outside } \\
\text { members than fraud firms" }\end{array}$ \\
\hline Nahar (2004) & $\begin{array}{l}\text { "To investigates the } \\
\text { roles of board } \\
\text { independence and } \\
\text { CEO duality on a } \\
\text { firms performance" }\end{array}$ & $\begin{array}{l}\text { ROA, ROE, } \\
\text { EPS, and } \\
\text { profit margin. }\end{array}$ & $\begin{array}{l}\text { "Board } \\
\text { independence } \\
\text { and CEO } \\
\text { duality" }\end{array}$ & $\begin{array}{l}\text { Descriptive, } \\
\text { correlation and } \\
\text { T-test }\end{array}$ & Malaysia & 412 Firms & $\begin{array}{l}\text { "Neither board independence, } \\
\text { leadership structure, nor the } \\
\text { joint effects of these two } \\
\text { showed any relations with } \\
\text { firms performance". }\end{array}$ \\
\hline $\begin{array}{l}\text { Chauhan, } \\
\text { Lakshmi, and } \\
\text { Dey(2016) }\end{array}$ & $\begin{array}{l}\text { "To explore the } \\
\text { relationship between } \\
\text { board composition } \\
\text { and performance of } \\
\text { Indian firms" } \\
\end{array}$ & Tobin Q & $\begin{array}{l}\text { "Board size, } \\
\text { board } \\
\text { composition, } \\
\text { and board } \\
\text { independence" } \\
\end{array}$ & $\begin{array}{l}\text { Descriptive, } \\
\text { correlation, } \\
\text { and T-test }\end{array}$ & India & 420 Firms & $\begin{array}{l}\text { "Board independence is } \\
\text { insignificant across all } \\
\text { categories in India" }\end{array}$ \\
\hline Johl et al.(2015) & $\begin{array}{l}\text { "To evaluate the } \\
\text { impact of board } \\
\text { characteristics on firm } \\
\text { performance" }\end{array}$ & $\mathrm{ROA}$ & $\begin{array}{l}\text { "Board meeting, } \\
\text { independence, } \\
\text { size, and } \\
\text { directors } \\
\text { accounting } \\
\text { expertise" }\end{array}$ & $\begin{array}{l}\text { Regression } \\
\text { model }\end{array}$ & Malaysia & 700 Firms & $\begin{array}{l}\text { "Independence does not affect } \\
\text { firm performance, while board } \\
\text { size and financial expertise are } \\
\text { positively associated with firm } \\
\text { performance". }\end{array}$ \\
\hline Arora(2012) & $\begin{array}{l}\text { "To examine the } \\
\text { impact of corporate } \\
\text { governance on firm } \\
\text { performance" }\end{array}$ & $\begin{array}{l}\text { ROA and } \\
\text { Tobin Q }\end{array}$ & $\begin{array}{l}\text { "Board size, } \\
\text { outside } \\
\text { directors, and } \\
\text { number of } \\
\text { meetings" } \\
\end{array}$ & $\begin{array}{l}\text { Descriptive, } \\
\text { correlation and } \\
\text { regression }\end{array}$ & India & 150 Firms & $\begin{array}{l}\text { Corporate governance has a } \\
\text { significant impact on firms' } \\
\text { performance. }\end{array}$ \\
\hline
\end{tabular}




\section{METHODOLOGY}

\subsection{Sample size and data collection}

We obtain the data for our study from several sources. Our secondary data are taken from the Prowess Q database and companies' annual financial reports. Financial data covers ten years from 2008 to 2017. We use a marketing-based measure (Tobin Q) and an accounting-based measure (ROA) to explain profitability.

Our study consists of 141 Bombay Stock Exchange listed companies, selected according to appropriate criteria: first, the company must have been established before 2008; secondly, data must be available for the period March 2008 to March 2017; finally, the company must exhibit no extreme outliers.

One company was excluded for the first reason, 41 companies' data were unavailable for the specified period and were therefore deleted in order to retain a balanced structured panel, and 17 companies were eliminated because of extreme outliers, which might influence the results of the regression model. Thus, the final sample consists of 82 companies that meet the above criteria.

\subsection{Model specification}

Hsiao (2003) and Baltagi et al. (2005) believe that there are different advantages in utilizing panel data analysis, including the efficiency of econometric estimates. Kyereboah-Coleman (2007) argued that panel data controls for individual heterogeneity and multicollinearity. Therefore, in applying a panel data set of 82 firms over ten years, linear regression models with fixed and random effect are used. The linear regression model produces more comparable and robust results.

On the basis of the above, and following Brooks (2014), Chowdhury and Rasid (2017), Masood, Ashraf, and Ashraf (2012) and Anbar and Alper (2011) in formulation of the panel data model, the following regression models are applied.

$$
\gamma_{n t}=\alpha+\beta x_{n t}+\varepsilon_{n t}
$$

Where $\gamma_{n t}$ indicates the dependent variable used in the study (firms' profitability), $\alpha$ denotes the intercept term of the explanatory variables, $\beta$ is a vector of parameter, while $x_{n t}$ is vector of observations which is $1 \times \mathrm{k}, \mathrm{t}=1, \ldots, \mathrm{T} ; \mathrm{n}=1, \ldots, \mathrm{N}$. The above regression equation can represented in this study as follows:

$$
\begin{aligned}
& (T Q)_{i t=} \alpha+\beta_{1}(B D C)_{i t}+\beta_{2}(S I Z)_{i t}+\beta_{3}(L E V)_{i t}+\beta_{4}(A G E)_{i t}+\varepsilon_{i t} \\
& (R O A)_{i t=} \alpha+\beta_{1}(B D C)_{i t}+\beta_{2}(S I Z)_{i t}+\beta_{3}(L E V)_{i t}+\beta_{4}(A G E)_{i t}+\varepsilon_{i t}(2)
\end{aligned}
$$

Where,

$(T Q)=$ Stands for the dependent variable Tobin $Q$.

$(\mathrm{ROA})=$ Stands for return on assets.

$(\mathrm{BDC})=$ Board of directors' composition

$(\mathrm{LEV})=$ leverage

$(\mathrm{SIZ})=$ size of firms measured by log of total assets

(AGE) Is the age of firms

$x)=$ Common $y$-intercept.

$(\beta 1-\beta 4)=$ coefficients of the explanatory variables

$(\varepsilon)_{\text {it }}=$ Stochastic error term of company $i$ at time

\subsection{Measurement of variables}

The study uses two financial measures: the marketing-based measure (Tobin Q) and accounting based measure (ROA) as proxies for firms' profitability. Board of directors' composition is used as an independent 
variable. Leverage, firms' size and age are control variables. Table 2 summarizes the variables and their measurement.

Table 2

Definition of variables

\begin{tabular}{|l|l|l|l|}
\hline \multicolumn{1}{|c|}{ Variable } & Symbol & \multicolumn{1}{|c|}{ Definition } & \multicolumn{1}{|c|}{ Existing Studies } \\
\hline Return on Assets & ROA & $\begin{array}{l}\text { It is measured by net income at the end of year divided } \\
\text { on total assets of the same period. The data are } \\
\text { collected from ProwessIQ database“. }\end{array}$ & $\begin{array}{l}\text { (Detthamrong, Chancharat\& Vithessonthi, } \\
\text { 2017; Chauhan et al., 2016; Pillai \& Al- } \\
\text { Malkawi, 2017, Yahya, et al., 2017; Yameen } \\
\text { et al., 2019; Mashayekhi \& Mohammad, } \\
\text { 2008) }\end{array}$ \\
\hline Tobin Q & TQ & $\begin{array}{l}\text { It is measured by market capitalization at the end of } \\
\text { the year scaled by the aggregate asset of the company } \\
\text { at the end of the same period. Data are extracted from } \\
\text { ProwessIQ database. }\end{array}$ & $\begin{array}{l}\text { (Kang \& Kim, 2011; Karaca \& Ekşi, 2012; } \\
\text { Ibrahim \& AbdulSamad, 2011) }\end{array}$ \\
\hline $\begin{array}{l}\text { Board } \\
\text { Directors } \\
\text { Composition }\end{array}$ & BDC & $\begin{array}{l}\text { No. of independent members in the board of directors } \\
\text { setting in the board. The data of the variable is is } \\
\text { extracted from the ProwessIQ database. }\end{array}$ & $\begin{array}{l}\text { ( Bhagat \& Blak, 2016; Agrawal \& } \\
\text { Knoeber, 1996; Johl et al., 2015; Mahadeo } \\
\text { et al., 2012; Nahar, 2004; Rhoades et al. } \\
\text { 2017; Mashayekhi \& Mohammad, 2008) }\end{array}$ \\
\hline Leverage & LEV & $\begin{array}{l}\text { It is defined by scaling the aggregate debt on } \\
\text { shareholder's equity at the end of the year. }\end{array}$ & $\begin{array}{l}\text { (Abuzayed, 2012; Afrifa, 2016; Afrifa \& } \\
\text { Padachi, 2016; Deloof, 2003; Garcia- } \\
\text { Teruel \& Martinez-Solano, 2007; Mehta, } \\
\text { 2017; Tauringana \& Afrifa, 2013) }\end{array}$ \\
\hline Firm Size & LOGTA & $\begin{array}{l}\text { It is defined as the natural logarithm of total assets. The } \\
\text { data are extracted from Prowess Q data base. }\end{array}$ & $\begin{array}{l}\text { Rizzotti \& Greco, 2013: Mehta, 2017; } \\
\text { Elangkumaran \& Karthika, 2013) }\end{array}$ \\
\hline Firm Age & AGE & $\begin{array}{l}\text { Number of years the company has been working. The } \\
\text { data are extracted from the Prowess Q database. }\end{array}$ & \begin{tabular}{l} 
(Afrifa, 2016; Afrifa \& Padachi, 2016) \\
\hline
\end{tabular} \\
\hline
\end{tabular}

\section{EMPIRICAL RESULTS AND DISCUSSION}

\subsection{Descriptive statistics}

Table 3 shows the summary statistics for all variables. The mean values of profitability measures Tobin $\mathrm{Q}$ and ROA are 1.52317 and 6.09739 with standard deviation of 1.994103 and 9.149767 , respectively. The average percentage of board of directors' composition is .530, indicating that at least $50 \%$ of board members in pharmaceutical companies are independent directors, ranging from.000 to 0.88 . Regarding controlling variables, the mean values of leverage, firms' size and age are 1.93607, 8.25990, and 33.82, respectively.

Table 3

Descriptive Statistics

\begin{tabular}{|l|c|c|c|c|c|}
\hline \multicolumn{1}{|c|}{ Variables } & N & Minimum & Maximum & Mean & Std. Deviation \\
\hline Tobin Q & 820 & .020 & 16.290 & 1.52317 & 1.994103 \\
\hline ROA & 820 & -50.900 & 92.640 & 6.09739 & 9.149767 \\
\hline BDC & 820 & .000 & .880 & .53005 & .120795 \\
\hline LEVE & 820 & .000 & 104.600 & 1.93607 & 9.361955 \\
\hline SIZ & 820 & 3.680 & 12.870 & 8.25990 & 1.864170 \\
\hline AGE & 820 & 1 & 110 & 33.82 & 18.819 \\
\hline
\end{tabular}

Note: "Tobin Q Stands for the financial performance of company measured, ROA Stands for return on assets, BDC is board of directors' composition, LEV Is leverage, SIZ is size of firms measured by log of total assets, AGE Is the age of firms" 


\subsection{Correlation matrix}

Table 4 presents the results of the empirical test. The correlation coefficients of study variables' estimation are similar to those previously reported in the literature. The board of directors' composition negatively and significantly correlates with Tobin $\mathrm{Q}(\mathrm{r}=-0.11$ and $\mathrm{P}$ value $>0.01)$ and $\mathrm{ROA}(\mathrm{r}=-0.78$ and $\mathrm{P}$ value $>0.05)$, which signifies that board composition has a low link with Tobin $\mathrm{Q}$ but a high association with ROA. The association between board of directors' composition and both Tobin Q and ROA could be explained by the low percentage of independent members on the board, as shown in Table 3. Some companies have no independent board members, which may affect their financial performance. However, this result contradicts that of Ameer et al. (2010) who found a positive and significant relationship with profitability. Similarly, leverage negatively and significantly correlates with the profitability of Indian pharmaceutical companies.

However, firms' size and age are positively and significantly associated with profitability defined by ROA and Tobin Q. The correlation matrix indicates whether the multicollinearity problem is absent or present in the model. Table 4 shows the correlation matrix and the results of the multicollinearity test, indicating that none of the independent variables has a high coefficient and suggesting that the model is not suffering from multicollinearity. This is confirmed by the Variance Inflation Factor (VIF) test (Field, 2009), as no independent variable in the model has a value of more than 10; in fact, all VIF values in our model are below 2 .

Table 4

Correlation Matrix

\begin{tabular}{|c|c|c|c|c|c|c|c|}
\hline \multicolumn{2}{|r|}{ Particulars } & TobinQ & ROA & BDC & LEVE & SIZ & AGE \\
\hline \multirow{2}{*}{ Tobin Q } & "Pearson Correlation" & 1 & & & & & \\
\hline & "Sig. (2-tailed)" & & & & & & \\
\hline \multirow{2}{*}{ ROA } & "Pearson Correlation" & $.395^{* *}$ & 1 & & & & \\
\hline & "Sig. (2-tailed)" & .000 & & & & & \\
\hline \multirow{2}{*}{ BDC } & "Pearson Correlation" & $-.113^{* *}$ & $-.078^{*}$ & 1 & & & \\
\hline & "Sig. (2-tailed)" & .001 & .025 & & & & \\
\hline \multirow{2}{*}{ LEVE } & "Pearson Correlation" & $-.099^{* *}$ & $-.107^{* *}$ & -.034 & 1 & & \\
\hline & "Sig. (2-tailed)" & .004 & .002 & .331 & & & \\
\hline \multirow{2}{*}{ SIZ } & "Pearson Correlation" & $.297^{* *}$ & $.116^{* *}$ & $.137^{* *}$ & $-.139^{* *}$ & 1 & \\
\hline & "Sig. (2-tailed)" & .000 & .001 & .000 & .000 & & \\
\hline \multirow{2}{*}{ AGE } & "Pearson Correlation" & $.190^{* *}$ & $.129^{* *}$ & .005 & -.065 & $.292^{* *}$ & 1 \\
\hline & "Sig. (2-tailed)" & .000 & .000 & .890 & .061 & .000 & \\
\hline \multicolumn{2}{|c|}{ VIF model 1} & & & 1.021 & 1.021 & 1.021 & 1.021 \\
\hline \multicolumn{2}{|c|}{ VIF model 2} & & & 1.021 & 1.021 & 1.132 & 1.095 \\
\hline
\end{tabular}

Note: “**. Correlation is significant at the 0.01 level (2-tailed)"

"*. Correlation is significant at the 0.05 level (2-tailed)".

"Tobin Q Stands for the financial performance of company measured, ROA Stands for return on assets, BDC is board of directors' composition, LEV Is leverage, SIZ is size of firms measured by log of total assets, AGE Is the age of firms"

\subsection{Regression analysis}

To find out whether the dependent variable (firms' profitability) is affected by the independent variables, regression analysis is a useful. That is a regression model was used to find the effect of the board of directors' composition on profitability in Indian pharmaceutical companies.

Before applying the regression model and running the analysis, we performed panel diagnostic tests, as shown in Table 5. 
Panel Diagnostic Tests

\begin{tabular}{|c|c|c|c|c|c|c|}
\hline \multicolumn{7}{|c|}{ Redundant Fixed Effects Tests } \\
\hline & \multicolumn{3}{|c|}{ Test cross-section fixed effects } & \multicolumn{3}{|c|}{ Test period fixed effects } \\
\hline & & Statistic & Prob. & & Statistic & Prob. \\
\hline Model 1 & Cross-section F & 6.894 & 0.000 & Period F & 1.294 & 0.236 \\
\hline Model 2 & Cross-section F & 22.724 & 0.000 & Period F & 5.993 & 0.000 \\
\hline \multicolumn{7}{|c|}{ Correlated Random Effects - Hausman Test } \\
\hline \multicolumn{3}{|c|}{ Test Summary } & Chi-Sq. Statistic & Chi-Sq. d.f. & Prob. & \\
\hline Model 1 & \multicolumn{2}{|l|}{ Cross-section random } & 12.624 & 4.000 & 0.013 & Fixed \\
\hline Model 2 & \multicolumn{2}{|l|}{ Cross-section random } & 77.647 & 4.000 & 0 & Fixed \\
\hline \multicolumn{7}{|c|}{ Heteroscedasticity Test: White } \\
\hline Model 1 & F-statistic & 1.625 & \multicolumn{2}{|c|}{ Prob. $\mathrm{F}(14,805)$} & 0.067 & \\
\hline Model 2 & F-statistic & 822.059 & \multicolumn{2}{|c|}{ Prob. F(14,805) } & 0.000 & \\
\hline
\end{tabular}

A unit root test was also conducted to find out whether all variables in the study are stationary at level or at first difference. The study used the Levin, Lin and Chu test, the Pesaran and Shin W-stat test, -and the Fisher Chi-square test for ADF and PP. Table 6 indicates that in all these tests all dependent and independent variables are stationary at first difference; in the Levin and PP tests, all variables were found to be stationary at level.

Table 6

Unite Root Test

\begin{tabular}{|c|c|c|c|c|c|c|c|c|}
\hline \multirow[t]{2}{*}{ Variable } & \multicolumn{4}{|c|}{ Level } & \multicolumn{4}{|c|}{ First difference } \\
\hline & Levin, Lin \& Chu & $\begin{array}{ll}\bullet & \text { Pes } \\
\text { aran and } & \text { Shin } \\
\text { W-stat } & \end{array}$ & $\begin{array}{l}\text { ADF } \\
\text { Fisher } \\
\text { Chi- } \\
\text { square }\end{array}$ & $\begin{array}{l}\text { PP } \\
\text { Fisher } \\
\text { Chi- } \\
\text { square }\end{array}$ & $\begin{array}{l}{[1] \quad \text { Le }} \\
\text { vin, Lin \& Chu } \\
\mathrm{t}^{*}\end{array}$ & $\begin{array}{l}\text { Pesaran } \\
\text { and Shin } \\
\text { W-stat }\end{array}$ & $\begin{array}{l}\text { ADF } \\
\text { Fisher } \\
\text { Chi- } \\
\text { square }\end{array}$ & $\begin{array}{l}\text { PP - Fisher } \\
\text { Chi-square }\end{array}$ \\
\hline \multicolumn{9}{|c|}{ Dependent variables } \\
\hline $\mathrm{ROA}$ & 0.0000 & 0.1009 & 0.0356 & 0.0000 & 0.0000 & 0.0000 & 0.0000 & 0.0000 \\
\hline Tobin Q & 0.0000 & 0.9410 & 0.6970 & 0.0052 & 0.0000 & 0.0005 & 0.0000 & 0.0000 \\
\hline \multicolumn{9}{|c|}{ Independent variables } \\
\hline $\begin{array}{l}\text { Board } \\
\text { compositio } \\
\text { ns }\end{array}$ & 0.0000 & 0.0105 & 0.0012 & 0.0000 & 0.0000 & 0.0000 & 0.0000 & 0.0000 \\
\hline Leverage & 0.0000 & 0.0000 & 0.0000 & 0.0000 & 0.0000 & 0.0000 & 0.0000 & 0.0000 \\
\hline Size & 0.0000 & 0.9944 & 0.8929 & 0.0000 & 0.0000 & 0.0000 & 0.0002 & 0.0000 \\
\hline Age & 0.0000 & 0.0000 & 0.0000 & 0.0000 & 0.0000 & 0.0000 & 0.0000 & 0.0000 \\
\hline
\end{tabular}

Several statistical tests were carried out to investigate the heterogeneity of the data and investigate the applicability of the panel data. Table 5 shows the results of Redundant Fixed Effects Tests, which suggests the use of a one-way variable intercept in cross-section for model (1) because cross-section F is significant $(\mathrm{p}<0.05)$, and period $\mathrm{F}$ is insignificant $(\mathrm{p}>0.05)$. For model $(2)$, Table 5 suggests the use of a two-way variable intercept in cross-section and time because cross-section $F$ is significant $(p<0.05)$, as is period $F$ $(\mathrm{p}<0.05)$. After examining the heterogeneity of the data, Hausman test is run to check whether a fixed or random effect model is more appropriate. The null hypothesis of the Hausman test states that random effect is appropriate; Table 5 indicates the use of the fixed effect model. The basic assumptions of least square regression are checked, and were met. Regarding their normal distribution the error terms were visualized in a histogram, and were found to be normally distributed in both models (1) and (2). Concerning 
autocorrelation, the results in Table 5 show that the value of Durbin-Watson lies between 1 and 2 in models (1) and (2), suggesting the absence of autocorrelation in both. Finally, in order to examine heteroscedasticity, White's test was applied; the results in Table 5 show that heteroscedasticity is not present in model (1).

Table 7 reveals that model (1) is fit for predicting the results, significant at the $1 \%$ level.The DurbinWatson value is 1.8750 , indictating the absence of autocorrelation. Furthermore, the adjusted $\mathrm{R}$ square is .035 , which means that $3 \%$ of the variation in the profitability of pharmaceutical companies measured by ROA can be attributed to changes in the independent variables. Moreover, board of directors' composition has a negative and significant effect on profitability as measured by ROA. This means that when the percentage of independent board members increases, ROA decreases. This finding is in line with Mahadeo et al. (2012) and Arora (2012), who advocate that board independence negatively impacts firms' profitability. However, the result contradicts Yameen et al. (2019), who argue that board composition is positively and significantly associated with profitability.

Regression Models

\begin{tabular}{|c|c|c|c|c|c|c|c|c|c|c|c|c|c|c|}
\hline \multicolumn{15}{|c|}{ Regression model return on assets is the dependent variable } \\
\hline \multicolumn{5}{|c|}{ Pooled regression model } & \multicolumn{5}{|c|}{ Fixed effect model } & \multicolumn{5}{|c|}{ Robust least squares model } \\
\hline Variables & B & $\begin{array}{c}\text { Std. } \\
\text { Error }\end{array}$ & $\mathrm{T}$ & Sig. & Variables & B & $\begin{array}{c}\text { Std. } \\
\text { Error } \\
\end{array}$ & $\mathrm{t}$ & Sig. & Variables & B & $\begin{array}{l}\text { Std. } \\
\text { Error }\end{array}$ & $\mathrm{t}$ & Sig. \\
\hline (Constant) & 4.89 & 1.897 & 2.578 & 0.01 & (Constant) & 14.913 & 5.051 & 2.952 & 0.003 & (Constant) & 1.375 & 1.078 & 1.276 & 0.202 \\
\hline BDC & -7.117 & 2.626 & -2.71 & 0.007 & $\mathrm{BDC}$ & -0.120 & 0.152 & -0.789 & 0.430 & BDC & -0.034 & 0.118 & -0.293 & 0.769 \\
\hline LEVE & -0.09 & 0.034 & -2.643 & 0.008 & LEVE & -0.467 & 0.158 & -2.951 & 0.003 & LEVE & -0.062 & 0.025 & -2.484 & 0.013 \\
\hline SIZ & 0.428 & 0.179 & 2.389 & 0.017 & SIZ & -0.526 & 0.884 & -0.595 & 0.552 & SIZ & -0.526 & 0.884 & 2.895 & 0.004 \\
\hline AGE & 0.048 & 0.017 & 2.736 & 0.006 & AGE & -0.103 & 0.129 & -0.797 & 0.426 & AGE & 0.055 & 0.013 & 4.260 & 0.000 \\
\hline $\begin{array}{l}\text { Durbin- } \\
\text { Watson } \\
\end{array}$ & \multicolumn{4}{|c|}{1.875083} & $\begin{array}{l}\text { Durbin- } \\
\text { Watson } \\
\end{array}$ & \multicolumn{4}{|c|}{1.445} & $\begin{array}{l}\text { Durbin- } \\
\text { Watson } \\
\end{array}$ & \multicolumn{4}{|c|}{ NA } \\
\hline R Square & \multicolumn{4}{|c|}{0.039973} & R Square & \multicolumn{4}{|c|}{0.450} & R Square & \multicolumn{4}{|c|}{0.046} \\
\hline $\begin{array}{l}\text { Adj. R } \\
\text { Square }\end{array}$ & \multicolumn{4}{|c|}{0.035} & $\begin{array}{l}\text { Adj. R } \\
\text { Square }\end{array}$ & \multicolumn{4}{|c|}{0.386} & $\begin{array}{l}\text { Adj. R } \\
\text { Square }\end{array}$ & \multicolumn{4}{|c|}{0.042} \\
\hline Prob. & \multicolumn{4}{|c|}{0.000} & Prob. & \multicolumn{4}{|c|}{0.000} & Prob. & \multicolumn{4}{|c|}{0.000} \\
\hline \multicolumn{15}{|c|}{ Regression model TobinQ is the dependent variable } \\
\hline \multicolumn{5}{|c|}{ Pooled regression model } & \multicolumn{5}{|c|}{ Fixed effect model } & \multicolumn{5}{|c|}{ Robust least squares model } \\
\hline Variables & B & $\begin{array}{c}\text { Std. } \\
\text { Error }\end{array}$ & $\mathrm{T}$ & Sig. & Variables & B & $\begin{array}{c}\text { Std. } \\
\text { Error } \\
\end{array}$ & $\mathrm{t}$ & Sig. & Variables & B & $\begin{array}{l}\text { Std. } \\
\text { Error }\end{array}$ & $\mathrm{t}$ & Sig. \\
\hline (Constant) & 0.510 & 0.017 & 30.793 & 0.000 & (Constant) & 0.502 & 0.040 & 12.493 & 0.000 & (Constant) & 0.523 & 0.017 & 30.077 & 0.000 \\
\hline BDC & 0.002 & 0.002 & 1.208 & 0.227 & BDC & 0.001 & 0.001 & 0.662 & 0.508 & $\mathrm{BDC}$ & 0.002 & 0.002 & 0.967 & 0.334 \\
\hline LEVE & 0.001 & 0.000 & 2.515 & 0.012 & LEVE & 0.005 & 0.001 & 3.700 & 0.000 & LEVE & 0.001 & 0.000 & 1.990 & 0.047 \\
\hline SIZ & -0.016 & 0.002 & -7.946 & 0.000 & SIZ & 0.024 & 0.007 & -10.762 & 0.000 & SIZ & -0.016 & 0.002 & -7.805 & 0.000 \\
\hline AGE & -0.001 & 0.000 & -6.630 & 0.000 & AGE & -0.011 & 0.001 & -10.762 & 0.000 & AGE & -0.001 & 0.000 & -6.982 & 0.000 \\
\hline $\begin{array}{l}\text { Durbin- } \\
\text { Watson } \\
\end{array}$ & \multicolumn{4}{|c|}{0.285} & $\begin{array}{l}\text { Durbin- } \\
\text { Watson } \\
\end{array}$ & \multicolumn{4}{|c|}{0.924} & $\begin{array}{l}\text { Durbin- } \\
\text { Watson } \\
\end{array}$ & \multicolumn{4}{|c|}{ NA } \\
\hline R Square & \multicolumn{4}{|c|}{0.172} & R Square & \multicolumn{4}{|c|}{0.764} & R Square & \multicolumn{4}{|c|}{0.172} \\
\hline $\begin{array}{l}\text { Adj. R } \\
\text { Square }\end{array}$ & \multicolumn{4}{|c|}{0.168} & $\begin{array}{l}\text { Adj. R } \\
\text { Square }\end{array}$ & \multicolumn{4}{|c|}{0.737} & $\begin{array}{l}\text { Adj. R } \\
\text { Square }\end{array}$ & \multicolumn{4}{|c|}{0.168} \\
\hline Prob. & \multicolumn{4}{|c|}{0.000} & Prob. & & 0.0 & & & Prob. & & & 000 & \\
\hline
\end{tabular}

In contrast, Table 7 shows that although model (2) is fit for predicting the results, significant at the level of $1 \%$, the Durbin-Watson value is 0.285 , signifying the presence of autocorrelation. Furthermore, the adjusted $\mathrm{R}$ square is 0.172 which indicates that $17 \%$ of the variation in profitability measured by ROA can be attributed to changes in the independent variables included in the study; the board of directors' 
composition positively and significantly influences profitability measured by Tobin Q. This means that the higher percentage of independent members on the board of directors reduces ROA. This could be attributed to the fact that dependent board members are in no better position to monitor the affairs of pharmaceutical companies. Importantly, Arora (2012) believes that the board of directors' composition negatively influences the profitability of Indian pharmaceutical firms. The result of this study contradicts Yameen et al. (2019), Kang et al. (2007), Hassan, Box, Ain and Hijazi (2016) and Chatterjee (2011), who argue that there is a negative relationship between board of directors' composition and firms' performance. Yermack (1996) also advocated that there is a negative and significant association between board composition and firms' performance.

\section{CONCLUSION}

The existing evidence from corporate governance research and firms' profitability affirms that the board of directors plays a significant role in reducing agency problems caused by absentee ownership. Therefore, this research sought to investigate the effect of board of directors' composition on the profitability of Indian pharmaceutical companies, using a sample of 82 listed companies over ten years. The target population was initially, 141 BSE-listed companies, reduced to a final sample of only 82 companies which met all the required criteria. Utilizing both SPSS and Eviews software programs, the empirical evidence was investigated. The least square regression model, fixed effect regression model and robust regression were used in analyzing the data.Both accounting-based and marketing-based measures were used as proxies for firms' profitability. Leverage, firms' size, and age were used as control variables. At least $50 \%$ of board members in pharmaceutical companies were found to be independent directors, with a range of .000 and 0.88 . The results revealed that board of directors' composition negatively and significantly affects firms' profitability measured by ROA, but positively and significantly affects profitability measured by Tobin Q. Further, firms' size and age positively and significantly impact profitability. The findings suggest that board composition might constitute a mechanism to enhance the profitability of firms. The present research has implications for academics, regulators, policy makers, boards and shareholders, shedding light on the importance of the effect of board of directors' composition on firms' profitability. Regulators can take decisions based on these results in evaluating the efficiency of corporate governance mechanisms. However, this research has some limitations which should be considered in interpreting the results. First, it was unable to cover all pharmaceutical companies because data were not available for non-listed companies. Future studies may find ways of investigating the non-listed pharmaceutical companies. Second, the study focused on board of director's composition and did not evaluate other mechanisms of corporate governance. Future researchers might investigate the impact on board of directors' composition on auditor choice, for example. Moreover, it would be interesting for researchers to examine the effect of institutional and government ownership on pharmaceutical companies' profitability.

\section{REFERENCES}

Abuzayed, B. (2012). Working capital management and firms' performance in emerging markets : The case of Jordan. International Journal of Managerial Finance, 8(2), 155-179. https://doi.org/10.1108/17439131211216620

Afrifa, G. A. (2016). Net working capital, cash flow and performance of UK SMEs. Review of Accounting and Finance, 15(1). https://doi.org/10.1108/RAF-02-2015-0031

Afrifa, G. A., \& Padachi, K. (2016). Working capital level influence on SME profitability. Journal of Small Business and Enterprise Development, 23(1), 44-63.https://doi.org/10.1108/JSBED-01-2014-0014

Agrawal, A., \&Knoeber, C. (1996). Firm performance and mechanisms to control agency problems between managers and shareholders. J. Finance. Quant. Anal, (31), 377-397. https://doi.org/10.2307/2331397 
Alabdullah, T. T. Y., Yahya, S., Nor, M. I., \& Majeed, F. Q. (2016). An investigation of corporate governance from a new perspective: Examining the financial performance of companies and the impact of executive turnover. Corporate Board: Role. Duties and Composition, 12(1), 53-69.

Ameer, R., Ramli, F., \& Zakaria, H. (2010). A new perspective on board composition and firm performance in an emerging market. Corporate Governance: The International Journal of Business in Society, 10(5), 647-661. https://doi.org/10.1108/14720701011085607

Anbar, A., \& Alper, D. (2011). Bank specific and macroeconomic determinants of commercial bank profitability: Empirical evidence from Turkey. Business and economics research journal, 2(2), 139-152.

Aren, S., Kayagil, S. Ö., \& Aydemir, S. D. (2014). The Determinants and effects of corporate governance level: Evidence from Istanbul Stock Exchange. Procedia - Social and Behavioral Sciences, 150, 1061-1070. https://doi.org/10.1016/j.sbspro.2014.09.118

Arora, A. (2012). Corporate governance and firm performance in Indian pharmaceutical sector. National Institute of Financial Management, 40(6), 537-550.

Arora, A., \& Sharma, C. (2015). Impact of firm performance on board characteristics: Empirical evidence from India. IIM Kozhikode Society \& Management Review, 4(1), 53-70. https://doi.org/10.1177/2277975215595559

Baltagi, B. H., Bratberg, E., \& Holmås, T. H. (2005). A panel data study of physicians' labour supply: the case of Norway. Health Economics, 14(10), 1035-1045. https://doi.org/10.1002/hec.991

Bassen, A. (2004). The implementation of good corporate governance by institutional investors. International Journal of Disclosure and Governance, 2(3), 244-263. https://doi.org/10.1057/palgrave.jdg.2040056

Beasley, M. S. (2016). An Empirical Analysis of the Relation between the Board of Director Composition and Financial Statement Fraud. Linked references are available on JSTOR for this article, 71(4), 443-465. https://www.jstor.org/stable/248566

Bebchuk, L. A., and J. A. Fried. (2003). Executive Compensation as an Agency Problem. Journal of Economic Perspectives 17, 71-92.

Bhagat, S., \&Blak, B. (2016). The uncertain relationship between board composition and firm performance. American Bar Association, 54(3), 921-963. https://www.jstor.org/stable/40687871

Bhagat, S. and Black, B. (2002), The non-correlation between board independence and long-term firm performance, Journal of Corporation Law, Vol. 27, pp. 231-274.

Brennan, N., \& McDermott, M. (2004). Alternative perspectives on independence of directors. Corporate Governance: An Interna- National Review, 12, 325-336. https://doi.org/10.1111/j.1467-8683.2004.00373.x

Brooks, C. (2014). Introductory econometrics for finance. Cambridge: Cambridge University Press.

Burton, P. (2000). Antecedents and consequences of corporate governance structures. Corporate Governance: $A n$ International Review, 8(3), 194-203.https://doi.org/10.1111/1467-8683.00198

Byrd, J., and E. Cooperman. (2010). Director Tenure and the Compensation of Bank CEOs. Managerial Finance, 36,86 102.

Chan, K. C., \& Li, J. (2008). Audit committee and firm value: evidence on outside top executives as expert-independent directors, corporate governance. International Review. https://doi.org/10.1111/j.1467-8683.2008.00662.x

Chatterjee, S. D. (2011). Board composition and performance in Indian firms: A comparative analysis empirical. The International Journal of Management Science and Information Technology (IJMSIT), 1-15. http://hdl.handle.net/10419/97877

Chauhan, Y., Lakshmi, K. R., \&Dey, D. K. (2016). Corporate governance practices, self-dealing, and firm performance: Evidence from India. Journal of Contemporary Accounting \& Economics, 12(3), 274-289. https://doi.org/10.1016/j.jcae.2016.10.002

Chowdhury, M. A. F. and Rasid, M. E. S. M. (2017). Determinants of performance of Islamic banks in GCC countries: Dynamic GMM approach. Advances in Islamic Finance, Marketing, and Management, 49-80. https://doi.org/10.1108/978-1-78635-899-820161005.

Conyon, M. J., and L. He. (2012). CEO Compensation and Corporate Governance in China. Corporate Governance: An International Review, 20, 575-592

Conyon, M. J., and L. He. (2011). Executive Compensation and Corporate Governance in China. Journal of Corporate Finance, 17, 1158-1175 
Core, J. E., R. W. Holthausen, and D. F. Larcker. (1999). Corporate governance, chief executive officer compensation, and firm performance. Journal of Financial Economics, 51, 371-406.

Deloof, M. (2003). Does working capital management affect profitability of Belgian firms ? Journal of Business Finance and.Accounting, 30(May). https://doi.org/10.1111/1468-5957.00008

Detthamrong, U., Chancharat, N., \&Vithessonthi, C. (2017). Corporate governance, capital structure and firm performance: Evidence from Thailand. Research in International Business and Finance, 42(July), 689-709. https://doi.org/10.1016/j.ribaf.2017.07.011

Elangkumaran, P., \&Karthika, T. (2013). An analysis of liquidity, profitability and risk: - A study of selected listed food, beverage and tobacco companies in Sri Lanka. 3rd International Conference, South Eastern University of Sri Lanka, (1), 1-7. http://dx.doi.org/10.2139/ssrn.2878916

Elsayed, K. K. (2007). Does CEO duality really affect corporate performance? Corporate Governance: An International Review, 15(6), 1203-1214. https://doi.org/10.1111/j.1467-8683.2007.00641.x

Erhardt, N. L., Werbel, J. D., \&Shrader, C. B. (2003). Board of director diversity and firm financial performance. Corporate Governance: An International Review, 11(2), 102-111. https://doi.org/10.1111/1467-8683.00011

Fama, E. F., and M. C. Jensen. (1983). Separation of Ownership and Control, Journal of Law \& Economics, 26, 301-325. Field, A. (2009). Discovering statistics using SPSS. Sage publications.

Fuentes, C. D. (2013). Governance for the tourism sector and its measurement. UNWTO Statistics and TSA. Issue Paper Series, 1-34. Retrieved from available: http://statistics.unwto.org/en/content/papers.

Garcia-Teruel, P. J., \& Martınez-Solano, P. (2007). Effects of working capital management on SME profitability. International Journal of Managerial Finance, 3(2), 164-177. https://doi.org/10.1108/17439130710738718

Geethalakshmi, A., \& Jothi, K. (2016). A Study on profitability position of Pharmaceutical Industry in India. International Journal of Advance Research in Computer Science and Management Studies, 4(4).

Gordon, J.N. (2007), The rise of independent directors in the United States, 1950-2005: of shareholder value and stock market prices. Stanford Law Review, 59(6), 1465-1568.

Hassan, Y. M., Box, P. O., Ain, A., \& Hijazi, R. H. (2016). The influence of corporate governance on corporate performance: evidence from Palestine Kamal Naser. Afro-Asian J. Finance and Accounting, 6(3), 269-287.

Higgs, D. (2003). Review of the role and effectiveness of non-executive directors. http://www.dti.gov.uk/cld/non execs review.

Hsiao, C. (2003) Analysis of panel data, 2nd ed. Cambridge University Press, New York.

Ibrahim, H., \&AbdulSamad, F. A. (2011). Corporate governance mechanisms and performance of public-listed familyownership in Malaysia. International Journal of Economics and Finance, 3(1), 105-115.

Jackling, B., \& Johl, S. (2009). Board structure and firm performance: evidence from India's top companies. Corp. Gov.: An Int. Rev, (17), 492-509.https://doi.org/10.1111/j.1467-8683.2009.00760.x

Javid, A. Y., and R. Iqbal. (2008). Ownership Concentration, Corporate Governance and Firm Performance: Evidence from Pakistan. The Pakistan Development Review 47: 643-659.

Johl, S. K., Kaur, S., \& Cooper, B. J. (2015). Board characteristics and firm performance: Evidence from Malaysian public listed firms. Journal of Economics, Business and Management, 3(2), 239-243. https://doi.org/10.7763/JOEBM.2015.V3.187

Kang, H., Cheng, M., \& Gray, S. J. (2007). Corporate governance and board composition: Diversity and independence of Australian Boards. Corporate Governance: An International Review, 15(2), 194 207.https://doi.org/10.1111/j.1467-8683.2007.00554.x

Kang, S., \& Kim, Y. (2011). Does earnings management amplify the association between corporate governance and firm performance ?: Evidence from Korea. International Business \& Economics Research Journal, 10(2), 5367.https://doi.org/10.19030/iber.v10i2.1793

Karaca, S. S., \&Ekşi, İ. H. (2012). The relationship between ownership structure and firm performance: An empirical analysis over İstanbul Stock Exchange(ISE) Listed Companies.International Business Research, 5(1), $172-181$.

Krause, R., Semadeni, M. and Cannella, A.A. (2014), CEO duality: a review and research agenda, Journal of Management, Vol. 40 No. 1, pp. 256-286

Kyereboah-Coleman, A. (2007) The impact of capital structure on the performance of microfinance institutions, The Journal of Risk Finance, Vol. 8 (1), pp.56-71. https://doi.org/10.1108/15265940710721082 
López-arceiz, F. J., Bellostas-pérezgrueso, A. J., Mariano, J., \& Rivera-torres, M. P. (2017). The role of corporate governance and transparency in the generation of financial performance in socially responsible companies. Spanish Journal of Finance and Accounting, 1-37. https://doi.org/10.1080/02102412.2017.1379798

Mahadeo, J. D., Soobaroyen, T., \& Hanuman, V. O. (2012). Board composition and financial performance: Uncovering the effects of diversity in an emerging economy. Journal of Business Ethics, 105(3), 375-388. https://doi.org/10.1007/s10551-011-0973-z

Mallin, C. (2001). Corporate governance and the bottom line. Corporate Governance: An International Review, 9(2), 7778 .

Mashayekhi, B., \& Mohammad, S. B. (2008). Corporate governance and firm performance in Iran. Journal of Contemporary Accounting \& Economics, 4(2), 156-172. https://doi.org/10.1016/S1815-5669(10)70033-3

Masood, O. and Ashraf, M. (2012). Bank-specific and macroeconomic profitability determinants of Islamic banks The case of different countries. Qualitative Research in Financial Markets, vol. 4(2/3), pp. 255-268. https://doi.org/10.1108/17554171211252565.

Mehta, M. S. P. (2017). Working capital management and firms' profitability : Evidence from emerging Asian countries. South Asian Journal of Business Studies, 6(1 pp).https://doi.org/10.1108/SAJBS-09-2015-0060

Mohamed, S., Ahmad, K., \&Khai, K. (2016). Corporate governance practices and firm performance: Evidence from top 100 public listed companies in Malaysia. Procedia Economics and Finance, 35(October 2015), 287-296. https://doi.org/10.1016/S2212-5671(16)00036

Mueller, D. C. (2006). The Anglo-Saxon approach to corporate governance and its applicability to emerging markets. Corporate Governance: An International Review, 14(4), 207-219.https://doi.org/10.1111/j.14678683.2006.00503.x

Nahar Abdullah, S. (2004). Board composition, CEO duality and performance among Malaysian listed companies. Corporate Governance: The International Journal of Business in Society, 4(4), 47-61. https://doi.org/10.1108/14720700410558871

Nilsson, G. O. (2007). Corporate governance in Turkey. European Business Organization Law Review (EBOR), 8(02), 195. https://doi.org/10.1017/S1566752907001954

Pillai, R., \& Al-Malkawi, H.-A. N. (2017). On the relationship between corporate governance and firm performance: Evidence from GCC countries. Research in International Business and Finance, (July), 0-1. https://doi.org/10.1016/j.ribaf.2017.07.110

Priego, A. M., \& Merino, E. (2016). Corporate governance effect on financial distress likelihood : Evidence from Spain. CómoCitar Este Artículo:, 19(1), 111-121. https://doi.org/10.1016/i.rcsar.2015.04.001

Rabelo, F. M., \&Vasconcelos, F. C. (2002). Corporate governance in Brazil. Journal of Business Ethics 37, $321-335$.

Rhoades, D. L., Rechner, P. L., \&Sundaram, C. (2017). Board composition and financial performance: A Meta-analysis of the influence of outside directors. Journal of Managerial Issues, 12(1), 7691.https://www.jstor.org/stable/40604295

Rizzotti, D., \& Greco, A. M. (2013). Determinants of board of statutory auditor and internal control committee diligence: A comparison between audit committee and the corresponding Italian committees. International Journal of Accounting, 48(1), 84-110. https://doi.org/10.1016/i.intacc.2013.01.007

Samra-Fredericks, D. (2000). Doing 'Boards-in-Action' research- An ethnographic approach for the capture and analysis of directors' and senior managers' interactive routines. Corporate Governance: An International Review, 8(3), $244-257$.

Singh Jaswal, S. (2014). Role of tourism industry in India's development. Journal of Tourism \& Hospitality, 04(02), 2-7. https://doi.org/10.4172/2167-0269.1000126

Switzer, L. N., \& Tang, M. (2009). The Impact of corporate governance on the performance of U. S. Small-Cap firms. International Journal of Business Research and Management, 14(4), 341-355

Talamo, G. (2011). Corporate governance and capital flows. Corporate Governance: The International Journal of Business in Society, 11(3), 228-243. https://doi.org/10.1108/14720701111138661

Tauringana, V., \& Afrifa, G. A. (2013). The relative importance of working capital management and its components to SMEs' profitability. Journal of Small Business and Enterprise Development, 20(3), 453-469. https://doi.org/10.1108/JSBED-12-2011-0029 
Vijayalakshmi, V., \& Srividya, M. (2015). A study on working capital management of pharmaceutical industry in India. Journal of Management and Science, 5(3), 59-80.

Weisbach, M. S. (2007). Optimal Executive Compensation versus Managerial Power: A Review of Lucian Bebchuk and Jesse Fried's Pay without Performance: The Unfufilled Promise of Executive Compensation. Journal of Economic Literature 45: 419-428

Yameen, M., Farhan, N. H., \& Tabash, M. I. (2019). The impact of corporate governance practices on firm's performance : An empirical evidence from Indian tourism sector. Journal of International Studies, 12(1), $208-228$. https://doi.org/10.14254/2071-8330.2019/12-1/14

Yermack, D. (1996). Higher market valuation for firms with a small board of directors. Journal of Financial Economics1, 40(1494), 185-211.https://doi.org/10.1016/0304-405X(95)00844-5

Zabri, S. M., Ahmad, K., \&Wah, K. K. (2016). Corporate governance practices and firm performance : Evidence from top 100 public listed companies in Malaysia. Procedia Economics and Finance, 35(October 2015), $287-296$. https://doi.org/10.1016/S2212-5671(16)00036-8 